\title{
Late- and post-glacial vegetation immigration patterns in Switzerland
}

Key words: plant immigration, glacial refugia, late- and postglacial, patterns of plant immigration, heather (Ericaceae), Alpine plantain (Plantago alpina), Swiss stone pine (Pinus cembra), spruce (Picea abies).

Mots-clés: immigration des plantes, refuge glaciaire, tardi-et postglaciaire, types d'immigration, Ericacées (Ericaceae), plantain alpin (Plantago alpina), pin cembro (Pinus cembra), épicéa (Picea abies).

\section{Summary}

General aspects of Swiss late- and post-glacial plant immigration patterns are briefly discussed. The following examples are mentioned: Ericaceae, Plantago alpina, Pinus cembra and Picea abies. The history of flora and vegetation provides important palaeoecological informations. Moreover, it gives evidence to the stability and age of quaternary plant communities and serve as criteria for gene conservation in situ. Finally, the knowledge of plant immigration ways can be a valuable source of plant breeding research.

\section{Investigation area}

The Swiss investigation area has been divided for this purpose into the following five regions: Jura. Plateau, Prealps, Central Alps and Southern Alps (including the South Alpine valleys of the Simplon pass area, the Val Bregaglia, the Poschiavo valley and the Val Müstair). For this purpose the whole data of published Swiss pollen analysis and plant macrofossil analysis have been checked, i. e. a total of 612 profiles and diagrams respectively. This information is established in the Swiss pollen data bank of the Department of Geography (Biogeography), University of Zurich.

\section{General aspects of plant immigration since the Late-Würmian}

Plant immigration, spread and establishment depends on a lot of complex factors or processes, i. e. diffuse biology and individual biological characteristics of plants, competition, succession, taphonomy, location of the glacial refugia, type of topography, role of nunataks, climate, geology, soil development, etc. (see for example H. WALTER and H.STRAKA 1970, H.J.B.BIRKS and H.H.BIRKS 1980, G. LANG 1994).

\section{General patterns of immigration and spread}

Generally, one can distinguish five different patterns of plant immigration and spread since the Late-Würmian (see fig. 1):

Late- and post-glacial immigration patterns of some plants

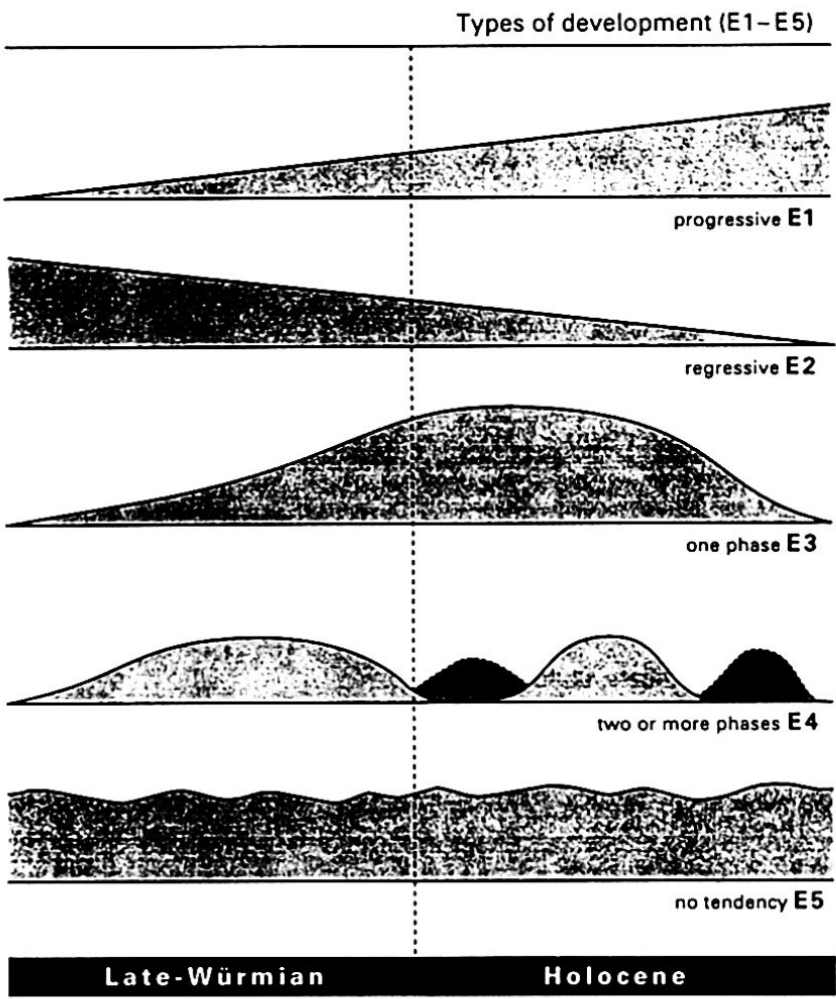

Fig.1 Late-and post-glacial immigration patterns of some plant species (scheme).

1. progressive development (E1), 2. regressive development (E2), 3. one phase development (E3), 4. two or more phases development (E4), 5. no tendency or very few information (E5).

Conradin A. Burga, Prof. Dr., University of Zurich, Department of Geography, Biogeography, Winterthurerstraße 190, 8057 Zurich $(\mathrm{CH})$. 


\section{Some examples of plant immigration patterns}

The pollen data of the heather family (Ericaceae) show in the Prealps and the Central Alps a typical progressive development (E1) since the Late-Würmian (see the timespace diagram, fig. 2). In Late-Würmian sediments this plant family is represented mainly by Calluna and the Vaccinium-type. The first pollen tetrads have been found in the Oldest Dryas. During the Bölling and mainly the Alleröd, the immigration of the Ericaceae has been more intensified. Calluna, Vaccinium and Rhododendron immigrated and established mainly as undershrubs of the Larix-Pinus cembra-forest in the Central Alps during the Alleröd and at the begin of the Holocene (PreborealBoreal). During the late Holocene, the Ericaceae shrubs often spread over a big area of the timberline-ecotone due to man influence (forest clearing, farming, pasturage).

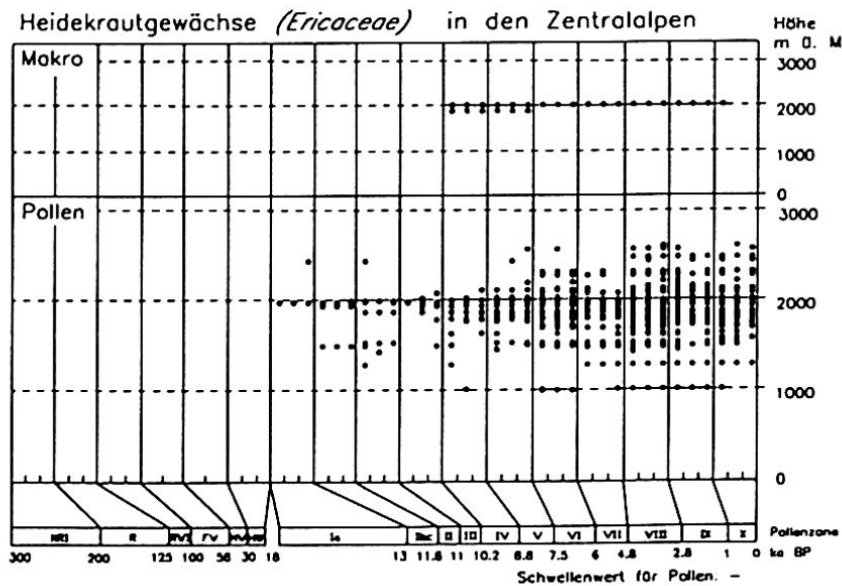

Fig. 2 Time-space diagram to the late- and post-glacial development of the Ericaceae in the Central Alps.

The opposite development pattern can be found for the Alpine plantain (Plantago alpina) in the Swiss Plateau (E2). The time-space diagram (fig. 3) shows a Late-Würmian main phase from the Oldest Dryas to the Younger Dryas and a very distinct recession since the Preboreal. Plantago alpina established first very quickly light demanding vegetation types like grassland and non forested areas. After the establishment of dense post-glacial forest vegetation, the area of the alpine plantain became very restricted in lower located regions, in contrast to higher elevated regions of the Alps (subalpine and alpine belt). In the Central Alps, the Swiss stone pine (Pinus cembra) immigrated and established during the Alleröd and achieved its maximal extension during the early and middle Holocene. The late Holocene recession is mainly due to man's impact on the subalpine vegetation belt (one phase development, E3). Fig. 4 shows two Central Alpine main areas of Pinus cembra, which have been established since the Boreal. One can distinguish a Western (Valais, Penninian Alps) and a Eastern (Grisons, Engadine valley, Avers valley) area with more or less a gap of Pinus cembra occurrence in the Furka and Grimsel pass region. This is probably due to different immigration ways from the Northeastern European glacial refugia.

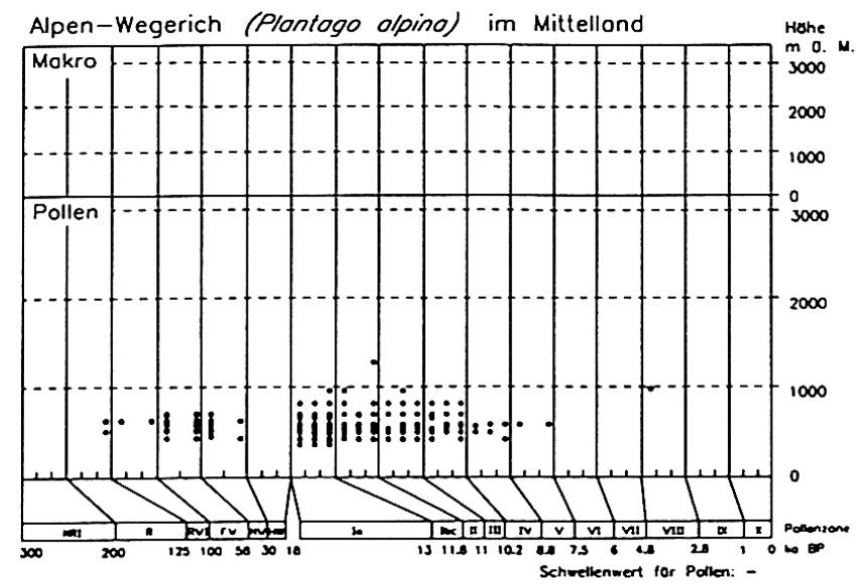

Fig. 3 Time-space diagram to the late- and post-glacial development of Plantago alpina in the Swiss Plateau.

The spruce (Picea abies) shows in the Alps a progressive development $(E 1)$ and a general immigration way from the Eastern to the Western Alps. Main immigration paths are areas in the Eastern and Southeastern Grisons, e.g. Lower Engadine valley, Upper Valtellina valley, Poschiavo valley and the Splügenpass area. At around 8000 BP, Picea abies immigrated from the Eastern Alps (Italy) into these areas. At $6500 \mathrm{BP}$ the spruce reached the line Säntis-Glaris-Oberalp pass-San Bernardino. 1000 years later, the area of Picea reached the region of Lucerne and the Lake of Thoune. At 5500 BP the Simplon pass and Col de la Forclaz were crossed northwards by the spruce. In the Southwestern Jura, the spruce of Mount Risoux immigrated at around 5500 BP probably from the Savoy Alps. There are a lot of palynological evidence concerning immigration and establishment of Picea abies (C. A. BURGA and R. PERRET 1997). These Western and Eastern Alpine main immigration paths of Picea have been confirmed by a complete different method, i. e. the investigation of the genetic variation of high elevated spruce populations in Switzerland (G.MÜLLER-STARCK 1995, C. A. BURGA and G. MÜLLER-STARCK in prep.). 


\section{Swiss stone pine (Pinus cembra)}

sites, $n=89$

- Holocene sites (Preboreal-Subatlantic)

with more than $5 \%$ Pinus cembra pollen

A Western Alpine area (Valais)

B Eastern Alpine area (Grisons)

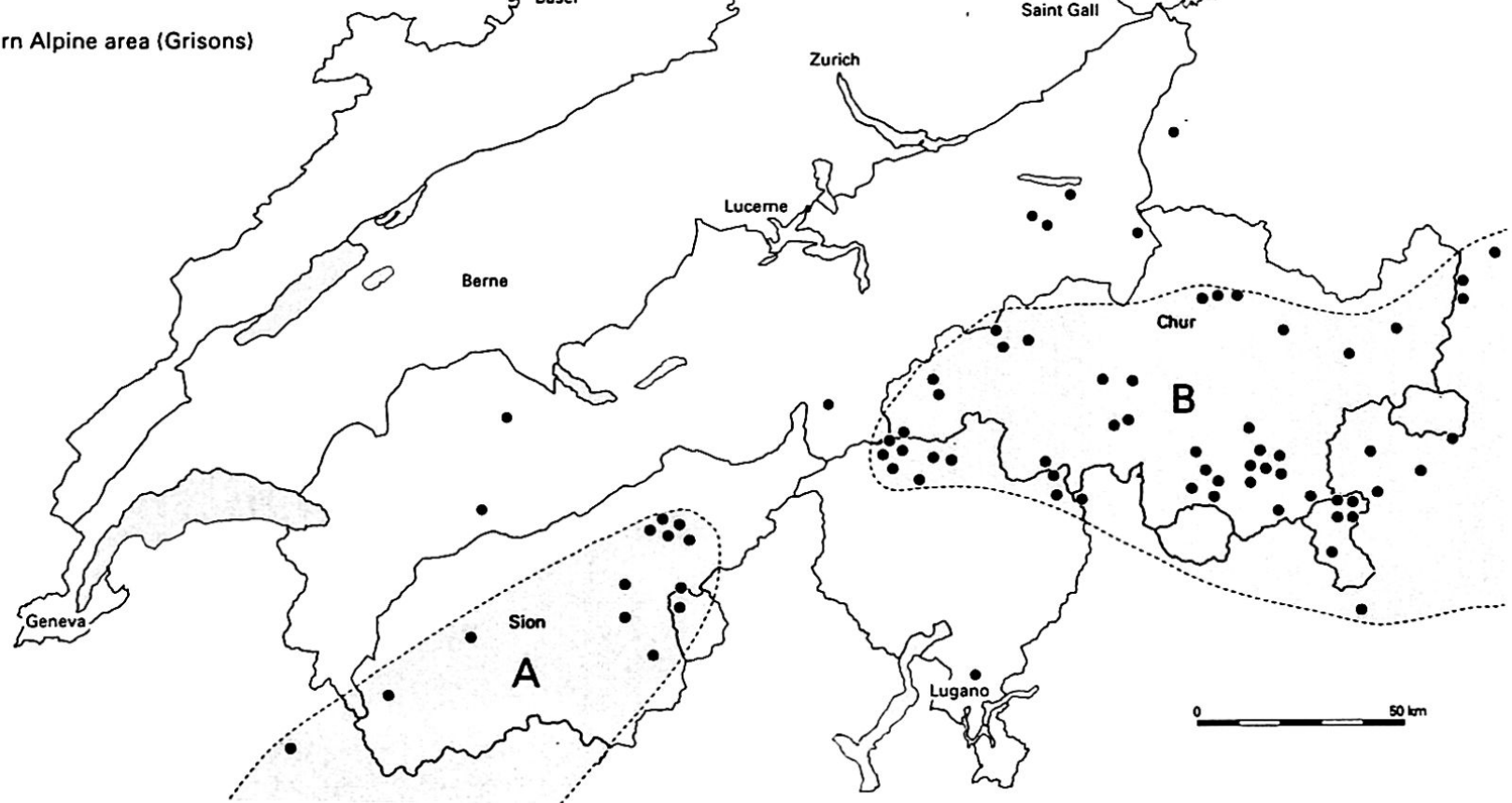

Fig. 4 Central Alpine occurrence of Pinus cembra according to pollen and macrofossil finds in Switzerland.

\section{Spruce (Picea abies)}

- sites, $\mathrm{n}=294$

_ immigration of spruce (radiocarbon years BP)

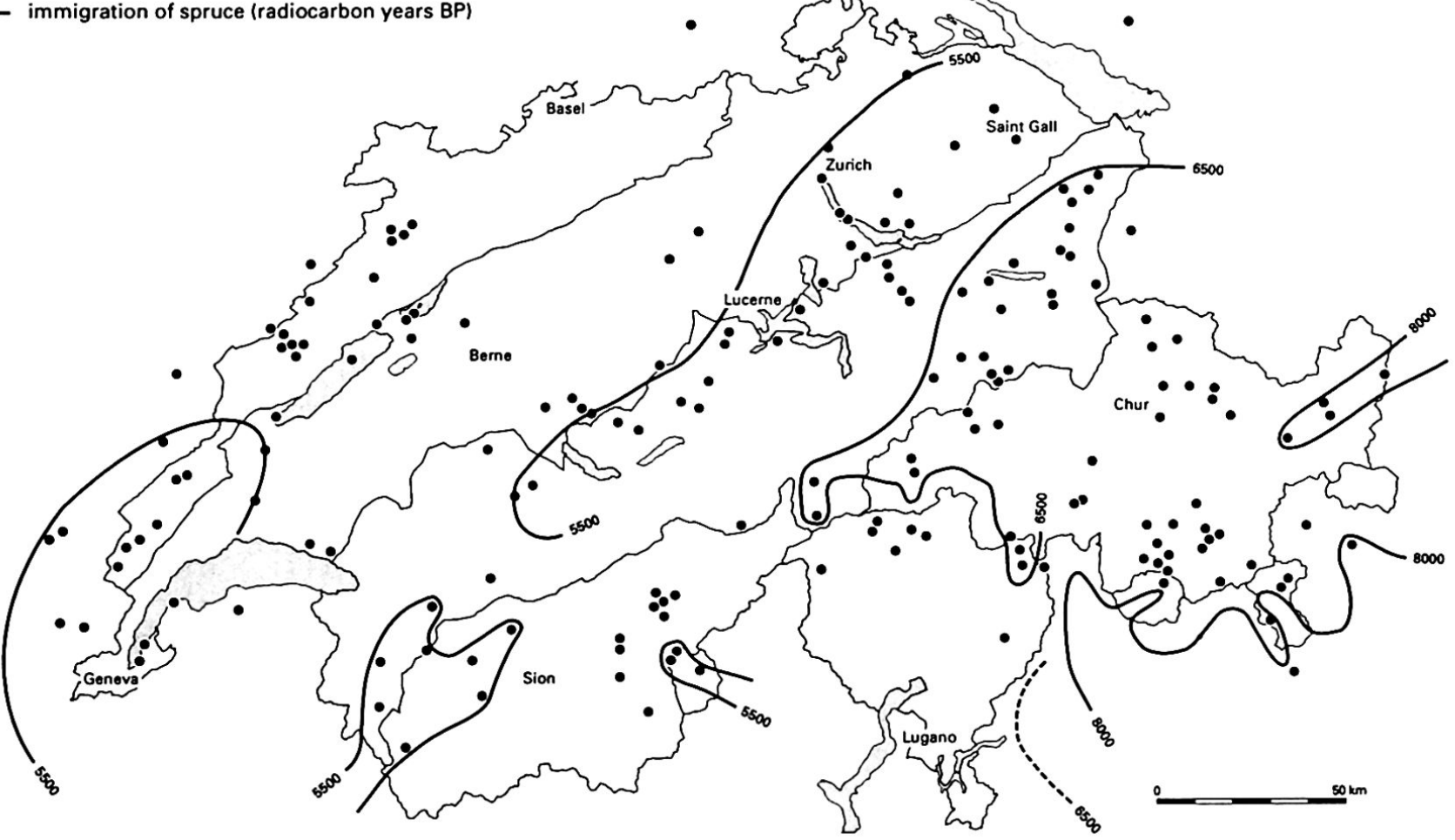

Fig. 5 Post-glacial immigration ways of Picea abies according to pollen and macrofossil finds in Switzerland. 


\section{Conclusion}

Flora and vegetation history provides valuable contributions to the development of climate and environment. The reconstruction of palaeoenvironments is connected with a lot of very complex factors (see section 2) and therefore are needed investigations based on different methods (see e.g. B.E.BERGLUND 1986). One particular aspect is the question of the stability and the age of plant communities. Based on our flora history knowledge, some forest communities like the larch-Swiss stone pine forest (Larici-Pinetum cembrae), the subalpine spruce forest (Piceetum subalpinum) and the subalpine alder scrub (Alnetum viridis) seem to be very stable plant communities.

The larch-Swiss stone pine forest established in the Central Alps ca. 12000 years ago (Alleröd) and is therefore one of the oldest forest communities of the Alps. The Piceetum subalpinum developed much later between 8000 and $6000 \mathrm{BP}$. The competition between spruce and Swiss stone pine led partly to a recession of the latter in the upper subalpine belt (see C.A.BURGA and R.PERRET 1997). The immigration and spread of Alnus viridis often is connected with the immigration of spruce. At the same time developed the typical tall herbaceous vegetation, which occurs together with the Alnetum viridis. Furthermore, the knowledge of plant immigration ways can be an important source of breeding research (e.g. Picea abies, Abies alba, G. MÜLLER-STARCK 1995, E. HUSSENDÖRFER and G. MÜLLER-STARCK 1994).

\section{References}

BERGLUND, B.E. (ed.) (1986): Handbook of Holocene Palaeoecology and Palaeohydrology. Wiley \& Sons, Chichester: 869.

BIRKS, H.J.B. \& BIRKS, H.H. (1980): Quaternary Palaeoecology. Arnold, London: 289.

BURGA, C.A. \& PERRET, R. (1997): Paläoökologie der Schweiz. Quaternary palaeoecology of Switzerland during the last 250000 years. Flora, vegetation and palaeoclimate. Ott, Thun: 1000

BURGA, C. A. \& MÜLLER-STARCK, G. (1997): Palynologic and genetic investigations of spruce (Picea abies) and silver fir (Abies alba). In prep.

HUSSENDÖRFER, E. \& MÜLLER-STARCK, G. (1994): Genetische Inventuren in Beständen der Weißtanne (Abies alba Mill.) - Aspekte der nacheiszeitlichen Wanderungsgeschichte. In: Schweiz. Z. Forstwes., 145 (12): 1021-1029.

LANG, G. (1994): Quartäre Vegetationsgeschichte Europas. Fischer, Jena: 462.

MÜLLER-STARK, G. (1995): Genetic Variations in High Elevated Populations of Norway Spruce (Picea abies [L.] KARST.) in Switzerland. Silvae Genetica, 44 (5-6): 356-362.

WALTER, H. \& STRAKA, H. (1970): Arealkunde. Floristischhistorische Geobotanik. Ulmer, Stuttgart: 478.

Am 20. Oktober 1996 ist Professor Gutersohn verstorben. Eine ausführlichere Würdigung wird in der nächsten Nummer 1/97 erscheinen.

Die Redaktion 